\title{
DUSTY EXPLOITING Of CHAFF PADDY UPON WHICH HARD MIXTURE TILE SOIL IN KARANG PENANG SAMPANG
}

\section{Sudijono}

\begin{abstract}
Abstrac
Chaff Paddy is external shares from paddy item. about/around $20 \%$ from paddy wight is paddy chaff and more or less $15 \%$ from composition lock up is lock up paddy which is always yielded is each time burned. ( Hara - 1986). Ash Lock up Paddy have pozolan element and contain silica. silica represent worthwhile chemicals and its application is very wide of strarting electronic area. mechanic. medical, building till other area. One of the silica serbuk exploiting is upon which ceramic making mixture of art ( hara. 1986). Dusty waste of this paddy chaff will be developed for the materials of bangunnan that is upon which mixture making of clay tile in Rock Penang Coat with lacquer so that can yield qualified Hat land;ground tile as according to SNI 03-2095-1998. Used by Mixture composition is heavy comparison $10 \mathrm{TL}$ : O ASP (control), $10 \mathrm{~T}: 1 \mathrm{ASP}, 10 \mathrm{TL}$ : 2 ASP, $10 \mathrm{TL}: 3 \mathrm{ASP}, 10 \mathrm{TL}: 4 \mathrm{ASP}, 10 \mathrm{TL}: 5 \mathrm{ASP}$. Dusty of Chaff Paddy to be used is beforehand sieved so that become refinement and clear of small stones and fibre so that/ to be easy to in course of and mixture printing of tile, is later; then mixed with clay and processed with printing of tile result of from tile printing;mould dried until tile is ready to burned, hereinafter process combustion of rose colored tile until. refinement as according to specification in SNI 032095-1998. Examination relate at SNI 03-2095-1998 about visible quality, decision of size measure, form, limber strength and absorbtion. From is sixth of mixture composition indicate that energy diffuse dusty clay tile water of terendah paddy chaff at III mixture ( $10 \mathrm{TL}: 2 \mathrm{ASP}$ ) equal to 6,28 \% below/under SNI 03-2095-1998 equal to $15 \%$ and enter in storey;level quality of II. Strong flex highest at III composition ( $10 \mathrm{TL}: 2 \mathrm{ASP}$ ) equal to 169,95 Singk / cm enter in storey;level quality of II tile and limber strength of minimum at VI composition ( $10 \mathrm{TL}: 5 \mathrm{ASP}$ ) equal to 133,67 Singk / cm ( SNI 03-2095-1998 min. 110 Singk / cm2
\end{abstract}

Keyword: Tile Clay, Dusty Waste of Chaff Paddy

\section{PENDAHULAN \\ Latar Belakang}

Sekam padi adalah bagian terluar dari butir padi, sekitar $20 \%$ dari bobot padi adalah sekam padi dan kurang lebih $15 \%$ dari komposisi sekam adalah abu sekam padi yang selalu dihasilkan setiap kali dibakar (Hara - 1986). Abu Sekam Padi yang memiliki unsur yang bermanfaat untuk bahan bangunan mempunyai sifat pozolan dan mengandung silika yang sangat menonjol (Ika Bali Agus Prakoso : hal 76). Silika merupakan bahan kimia yang bermanfaat dan aplikasinya sangat luas mulai bidang elektronik, mekanik, medis, bangunan hingga bidang-bidang lainnya. Salah satu pemanfaatan serbuk silika adalah sebagai bahan campuran pembuatan keramik seni (hara, 1986). dan masih banyak lagi manfaat lain dari silika.

Ditinjau data komposisi kimiawi, sekam mengandung beberapa unsur kimia penting seperti dapat dilihat di bawah :
1. Komposisi kimia sekam padi menurut Suharno (1979):

- Kadar air : 9,02\%

- Protein kasar : 3,03\%

Lemak : 1,18\%

- Serat kasar : 35,68\%

- Abu : 17,17\%

Karbihidart dasar : 33,71

2. Komposisi kimia sekam padai menurut DTC - IPB :

- Karbon (zat arang) : 1,33\%

- Hidrogen : $1,54 \%$

- Oksigen : $33,64 \%$

- Silika : 16,98\% 
Dengan komposisi kandungan kimia seperti di atas, sekam dapat dimanfaatkan untuk berbagai keperluan di antaranya:

- Sebagai bahan baku pada industri kimia, terutama kandungan zat kimia furfural yang dapat digunakan sebagai bahan baku dalam berbagai industri kimia,

- Sebagai bahan baku pada industri bahan bangunan, terutama kandungan silika (Si02) yang dapat digunakan untuk campuran pada pembuatan semen portland, bahan isolasi, huskboard dan campuran pada industri bata merah, (c) sebagai sumber energi panas pada berbagai keperluan manusia, kadar selulosa yang cukup tinggi dapat memberikan pembakaran yang merata dan stabil $(w w w$, smallerab. com).

Padi merupakan tanaman pokok dan makanan pokok penduduk Indonesia yang merupakan negara agraris penghasil padi. Panen padi di daerah basah dan daerah kering seluas kurang lebih 8.000.000. ha dengan produksi beras rata-rata 1,6 ton per ha. Hasil padi kurang lebih 26.300 .000 ton per tahun dengan demikian setara dengan lebih kurang 6.500.000. ton sekam padi per tahun. (Sumber Loka Karya Nasional). Menurut jenis padinya akan diperoleh sekitar 20-25\% sekam padi. 10-12\% katul dan 63$70 \%$ beras. Dari limbah sekam padi tersebut tentunya akan timbul masalah limbah bagi pabrik penggilingan padi. Sehingga cara yang ditempuh untuk membuang kelebihan limbah tersebut khususnya sekam padi adalah dengan membakarnya ditempat terbuka. Dalam pembakaran biasanya sekam mengahasilkan $20 \%$ abu silika sebagai komponen utamanya (Departemen Perindustrian dan Perdagangan Surabaya).

Untuk mendapatkan bahan baku abu sekam padi terdapat banyak tempat yang bisa diambil dan menurut pengamatan dilapangan terdapat 3-5 tempat penggilingan padi disetiap desa yang terdapat di sampang terutama di kecamatan Omben serta kecamatan-kecamatan lainnya. Pada setiap penggilingan padi akan menghasilkan sampai 1 ton perhari sekam padi hal ini dapat dilihat melalui sekam padi yang keluar dari penggilingan.

Adapun kronologi untuk mendapatkan abu sekam padi adalah membakar sekam padi diruangan terbuka dengan api yang cukup sehingga dapat membakar keseluruhan sekam padi sampai berwarna putih, setelah menjadi abu sekam maka abu sekam tersebut diayak dengan menggunakan ayakan terkecil agar menghasilkan abu sekam padi yang halus dan mudah untuk dicampur dengan tanah liat.

Dari hasil pengamatan dilapangan industri genteng yang menggunakan bahan baku tanah liat semakin lama akan terus habis tanpa adanya altematif lain untuk mengganti atau mengurangi pemakaian bahan baku tanah. Dibutuhkan beberapa altematif untuk pengurangan bahan baku, sal ah satunya adalah dengan menggunakan campuran hasil pembakaran sekam padi yaitu Abu Sekam Padi sebagai bahan campuran bahan baku genteng tanah liat, sehingga akan menghasilkan genteng yang tidak retak, corak yang baik serta kekuatan yang baik pula dan akan mengurangi penggunaan bahan baku tanah liat tentunya.

Genteng yang baik merupakan genteng yang memenuhi persyaratan dan sesuai dengan Standart Nasional Indonesia (SNI) tentang ketepatan ukuran, ketahanan terhadap rembesan air, peresapan air serta beban lentur yang diperoleh dan lain sebagainya, secara umum dapat disyaratkan bahwa genteng mempunyai klasifikasi sesuai dengan Standart Nasional Indonesia (SNI 03-2095-1991) yaitu genteng tingkat I, II, III, IV dan genteng tingkat V. Genteng yang baik adalah genteng tingkat I yang mempunyai klasifikasi permukaan yang utuh dan licin, bila dipukul menghasilkan suara yang nyaring dan kerapatan pemasangan harus baik serta warna sama untuk seluruh partai. Apabila terdapat cacat-cacat sedikit atau retak rambut maka sesuai dengan peraturan Standart Nasional Indonesai yaitu cacat/permukaan genteng yang terdapat bintik-bintik hitam benjolan-benjolan dan lekukan yang disebabkan oleh bagian permukaan yang lepas. (Departemen Perindustrian, SNI.03-2095. 1991 :2-3). Klasifikasi menurut Standart Nasional Indonesia (SNI 03-2095-1998) genteng dibagi menjadi tiga jenis yaitu genteng kecil dengan panjang minimum $275 \mathrm{~mm}$, genteng sedang mempunyai panjang minimum 300 $\mathrm{mm}$ dan genteng besar mempunyai panjang minimum 400 mm (SNI 03-2095-1998). Dengan penjelasan di atas maka perlu adanya alternatif dan solusi untuk memanfatkan limbah abu sekam padi dan upaya untuk meningkatkan kwalitas mutu genteng yang ada di Karang Penang Sampang maka diupayakan untuk melakukan penelitian pemanfaatan abu 
sekam padi sebagai bahan campuran pada pembuatan genteng tanah Hat di Karang Penang Sampang dengan mengacu pada Standart Nasional Nasional (SNI)

\section{Rumusan Masalah}

Sesuai dengan uraian latar belakang, maka peneliti merumuskan masalah sebagai berikut

1. Apakah Abu Sekam Padi bisa dijadikan sebagai bahan campuran pembuatan genteng tanah Hat di Karang Penang Sampang

2. Komposisi campuran mana yang terbaik untuk dijadikan sebagai campuran genteng tanah liat di Karang Penang Sampang

\section{Tujuan Penelitian}

Adapun tujuan dari penelitian adalah untuk mengetahui apakah limbah Abu Sekam Padi dapat dimanfaatkan sebagai bahan campuran pada pembuatan genteng tanah Hat di Karang Penang Sampang berdasarkan Standart Nasional Indonesia (SNI)

\section{Batasan Masalah}

Agar pokok permasalahan pada penelitian tidak meluas, maka dibatasi pada pembahasan masalah sebagai berikut:

1. Abu Sekam Padi yang digunakan adalah Abu Sekam Padi yang dihasilkan dari pembakaran tradisional dengan pembakaran sampai berwarna putih

2. Abu sekam diayak dengan menggunakan ayakan terkecil sehingga menjadi halus dan dapat tercampur dengan tanah liat

3. Genteng sebagai benda uji adalah genteng tanah liat yang diproduksi dari desa Karang Penang Sampang

\section{Manfaat Hasil Penelitian}

Penelitian dengan memanfaatkan Abu Sekam Padi pada pembuatan genteng tanah liat di Karang Penang Sampang diharapkan memberi manfaat sebagai berikut :

1. Memberikan informasi manfaat lain dari Abu Sekam Padi untuk dijadikan bahan campuran genteng tanah liat.
2. Dapat menghemat pemakaian tanah liat untuk bahan baku dalam pembuatan genteng tanah liat

3. Meningkatkan mutu dan kwalitas produksi genteng tanah liat dalam upaya peningkatan nilai tambah ekonomi bagi industri rumah di Karang Penang Sampang.

4. Menambah wawasan dan ilmu pengetahuan mengenai genteng tanah liat

5. Mengangkat kedudukan Abu Sekam Padi menjadi bahan yang lebih bermanfaat

6. Dapat dipakai sebagai bahan pertimbangan untuk bahan tambahan pengetahuan dan refrensi perpustakaan Universitas Negeri Surabaya.

\section{METODE PENELITIAN}

Metode yang digunakan adalah metode eksperimen dengan pembuatan benda uji genteng tanah liat dengan bahan baku campuran Abu Sekam Padi, selanjutnya dilakukan sesuai Standart Nasioanal Indonesia (SNI) mengenai pembagian genteng berdasarkan mutu atau tingkatan, ketepatan ukuran, bentuk, ketahanan terhadap rembesan dan beban lentur.

\section{A. Populasi dan Sampel}

Populasi dan sampel dalam penelitian ini adalah genteng tanah liat dibuat disalah satu Usaha Industri genteng di Karang Penang Sampang, dengan bahan baku tanah liat dicampur dengan Abu Sekam Padi, adapun rencana campuran antara tanah liat dan Abu Sekam Padi dengan nilai perbandingan seba

Tabel 3.1 Rencana Campuran Benda Uji

\begin{tabular}{|c|c|c|c|}
\hline \multirow[t]{2}{*}{ No } & \multirow[t]{2}{*}{ Campuran } & \multicolumn{2}{|c|}{$\begin{array}{c}\text { Nilai Perbandingan } \\
(\mathrm{Kg})\end{array}$} \\
\hline & & $\begin{array}{c}\text { Tanah } \\
\text { Liat }\end{array}$ & $\begin{array}{l}\text { Abu Sekam } \\
\text { Padi }\end{array}$ \\
\hline 1 & Campuran 1 & 10 & 0 \\
\hline 2 & Campuran 2 & 10 & 1 \\
\hline 3 & Campuran 3 & 10 & 2 \\
\hline 4 & Campuran 4 & 10 & 3 \\
\hline 5 & Campuran 5 & 10 & 4 \\
\hline 6 & Campuran 6 & 10 & 5 \\
\hline
\end{tabular}

Sumber : Rencana Penelitian 
B. Jumlah Benda uji

Tabel 3.2 Rencana Jumlah Benda Uji

\begin{tabular}{ccccc}
\hline No. & $\begin{array}{c}\text { Kelompok } \\
\text { Benda Uji }\end{array}$ & $\begin{array}{c}\text { Uji Penyerapanyak Benda Uji } \\
\text { Air (Buah) }\end{array}$ & $\begin{array}{c}\text { Uji Kuat Lentur } \\
\text { (Buah) }\end{array}$ & $\begin{array}{c}\text { Jumlah } \\
\text { (Buah) }\end{array}$ \\
\hline 1 & Campuran 1 & 10 & 6 & 16 \\
2 & Campuran 2 & 10 & 6 & 16 \\
3 & Campuran 3 & 10 & 6 & 16 \\
4 & Campuran 4 & 10 & 6 & 16 \\
5 & Campuran 5 & 10 & 6 & 16 \\
6 & Campuran 6 & 10 & 6 & 16 \\
& Total & 60 & 36 & 96 \\
\hline
\end{tabular}

\section{Variabel Penelitian}

Berdasarkan masalah penelitian dan hipotesis penelitian, maka variabel-veriabel yang diteliti adalah variabel yang menentukan beban lentur rata-rata, fisik genteng dan perembesan genteng dari pemeriksaan sejumlah benda uji. Adapun variabel-variabel tersebut adalah :

1. Variabel bebas

Variabel bebas adalah veriabel yang hendak diuji pengaruhnya terhadap tingkah laku yang terjadi. Jadi variabel bebas dari penelitian genteng tanah liat dengan campuran abu sekam padi adalah genteng tanah liat yang di produksi oleh industri genteng di Karang Penang Sampang dengan campuran yang berbeda-beda.

2. Variabel terikat / tergantung Variabel terikat adalah variabel yang terjadi akaibat variabel bebas yang telah ditentukan. Variabel terikat dari penelitian genteng tanah liat dengan campuran abu sekam padi adalah mengacu dengan Standart Nasional Indonesia (SNI)

3. Variabel kontrol

Variabel kontrol mencakup dari semua variabel yang disamakan, baik untuk kelompok eksperimen maupun kelompok pembanding. Adapun variabel yang dikontrol dalam penelitian genteng tanah liat dengan campuran abu sekam padi adalah :

a. Bahan baku tanah liat diambil dari jenis dan lokasi yang sama didaerah Karang Penang Sampang

b. Alat yang digunakan untuk memproses genteng tanah liat sama

c. Proses pencampuran komposisi sama

d. Tempat pembuatan genteng tanah liat sama

e. Peralatan dan laboratorium yang digunakan adalah sama f. Mesin yang digunakan untuk mencetak genteng tanah liat sama

\section{Tempat Penelitian}

Pembuatan genteng tanah liat dilaksanakan di Industri Genteng yang ada di Karang Penang Sampang. Pengujian benda uji dilaksanakan di laboratorium beton dan bahan Jurusan Teknk Sipil Universitas Negeri Surabaya.

\section{Cara Pengambilan Contoh benda uji}

Pengambilan contoh dilakukan petugas yang berwenang dan tidak memihak, serta dibuat berita acaranya. Diusahakan agar contoh yang diambil mencerminkan keadaan seluruh partai (SNI 03-2095-1998). Pengambilan contoh harus dilakukan secara acak pada berbagai partai tersebut.

1. Jumlah contoh yang diuji

a. Dalam semua keadaan jumlah contoh yang diambil sebanyak 50 buah genteng.

b. Untuk tanding sampai dengan 500.000 buah genteng diambil masing-masing 10 buah dari tiap kelompok yang berjumlah 50.000 buah genteng.

c. Tiap kenaikan 100.000 buah genteng diambil paling sedikit 5 buah genteng.

2. Pengiriman contoh

Untuk pengiriman contoh ketempat pengujian, contoh harus dikemas/diikiat dan diberi label contoh benda uji, sehingga tidak pecah atau cacat dalam pengangkutan. Pada setiap pengiriman contoh harus disertai keterangan yang memuat:
a. Alamat, nama perusahaan, merek dan tanggal pengambilan contoh
b. Berita acara dan label contoh diuji ditandatangani oleh pengambil contoh dan pemilik/pengusaha
c. Banyak contoh yang diuji 

d. Risalah pengambilan contoh dan mencantumkan pengambilan contoh
cara-cara

\section{Cara Pengujian Genteng Tanah Liat}

Semua genteng yang akan diuji harus

dalam keadaan kering

1. Mutu Tampak

Siapkan jumlah contoh uji 10 buah. Amati dan catat secara seksama keadaan permukaan semua contoh genteng untuk diperiksa dibawah sinar langsung yang sukup terang, apakah terdapat retak-retak, bintik hitam, benjolan dan lekukan yang disebabkan oleh bagian permukaan yang lepas atau cacat lain, pemakaian warna dan bentuk (SNI 03-2095-1998)

2. Ketetapan Ukuran

Penentuan panjang, lebar dan kaitan genteng dengan peralatan ;

- Jangka Sorong $600 \mathrm{~mm}$ ketelitian $0.05 \mathrm{~mm}$

- Jangka Sorong $300 \mathrm{~mm}$ keteltiian $0.02 \mathrm{~mm}$

Prosedur:

- Siapkan jumlah contoh uji 10 buah genteng

- Ukur panajng dan lebar masngmasing genteng pada dua tempat pengukuran yang berbeda

- Hitung rata-rata nilai pengukuran panjang dan lebar tersebut

- Catat ukuran panjang dan lebar terbesar dan terkecil

- Ukur kaitan masing-masing genteng untuk panjang, lebar dan tinggi

- Hitung rata-rata dari panjang, lebar dan tinggi

(Standart Nasional Indonesia SNI 032095-1998)

3. Penyerapan Air

Peralatan :

- Oven 200 derajat celcius ketelitian 2 derajat

- Neraca teknis kapasitas $10 \mathrm{~kg}$ ketelitian 1 gram

- Bak perendaman genteng

- Lab lembab

Prosedur :

- $\quad$ Siapkan contoh 10 buah genteng

- Keringkan genteng dalam oven pada suhu 110 derajat celcius +5 derajat celcius selama 2 jam

- Timbang genteng dalam keadaan kering $(\mathrm{K})$, gram

- Rendam genteng tersebut dalam air selama 24 jam
- Kemudian timbang basah dengan dengan menyeka permukaan genteng lebih dahulu dengan lap lembab, catat berat contoh (w) gram

- Hitung peresapan air genteng sebagai berikut :

$=\frac{\text { berat } W}{\text { berat } V} \times 100 \%$

Hitung rata-rata \% peresapan air genteng (Standart Nasional Indonesia SNI 03-2095-1998)

4. Beban Lentur

Pengujian beban lentur dilakukan terhadap minimal 6 bauh genteng. Alatalat penguji terdiri dari mesin tekan, pen urn pu terbuat dari spesi dengan tebal minimal $20 \mathrm{~mm}$ dan lebar maksimal 30 $\mathrm{mm}$

Cara pengujian dilakukan dengan cara : Penumpu dipasang dengan jarak $20 \mathrm{~cm}$ dan pembebanan dipasang di tengah - tengah diantara penumpu. Pembebanan dikondisikan sedemikian rupa sehingga gaya-gaya yang bekerja pada genteng terbagi rata pada seluruh lebar genteng. Pembebanan dilakukan secara perlahanlahan dengan penambahan beban gaya 5 $\mathrm{kg} /$ detik. Beban maksimal adalah beban tertinggi pada saat genteng patah. Beban lentur genteng adalah hasil rata-rata dari 6 buah genteng uji dibulatkan sampai kg gaya. Apabila 1 dari 6 buah genteng yang di uji mempunyai beban lentur kurag dari harga minimal maka pengujian diulangi dengan 6 buah genteng yang lain apabila dalam pengujian ulangan hal tersebut terjadi lagi, maka mutu genteng dinyatakan satu tingkat lebih rendah. (Standart Nasional Indonesia SNI 03-2095-1998)

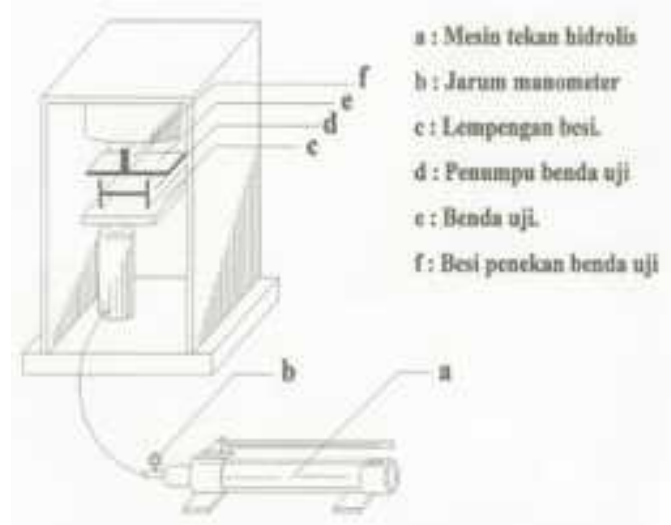

Gambar 3.1. Set up lentur genteng beton (Suprapto, 2005) Teknik Anlisa Data 
Analisa data menggunakan analisis deskriptif dengan menggunakan grafik dan tabel. Analisis ini dilaksanakan dengan

1. Keadaan fisik genteng yang didapat adalah berat genteng tanah liat. Tebal genteng tanah liat, tinggi kaitan, kedalam alur, dan kerataan harus sesuai dengan Standart Nasional Indonesia (SNI)

2. Sumber buku panduan labshet praktek uji bahan, setelah mencari gaya tekan, jika yang terukur tegangan maka dihitung :

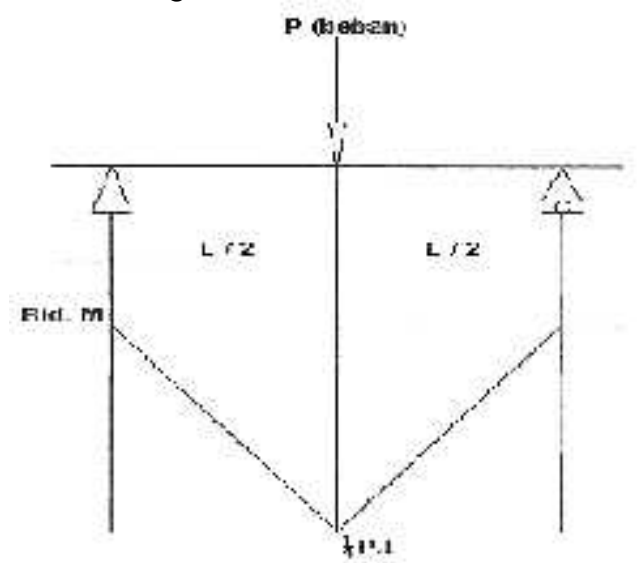

(Sumber : Istimawan Dipohusodo (1999), Struktur Beton Bertulang)

$$
\begin{aligned}
& M=\frac{1}{2} P I_{L}=\frac{a}{4} P L=\frac{P L}{4} \\
& W=\frac{a}{b} b h^{2} \text { (Rumus balok) } \\
& \sigma l t=\frac{M X}{W X}=\frac{P_{1} L}{4} \frac{b, h^{*}}{\sigma} \\
& =\frac{F \cdot L}{4}: \frac{G}{b \cdot h^{2}} \\
& =\frac{F L}{2}: \frac{d}{b \cdot h^{2}} \\
& =\frac{d \mu d}{2 b h^{2}} \\
& \sigma i t=\frac{d \mu_{i}}{2 \cdot \vec{b} \hbar^{2}}\left(\mathrm{~kg} / \mathrm{Cm}^{2}\right)
\end{aligned}
$$

Keterangan :

$$
\begin{array}{ll}
\sigma L t & =\text { Tegangan Lentur } \\
\mathrm{P} & =\text { Beban Lentur } \\
\mathrm{L} & =\text { Panjang Benda Uji } \\
\mathrm{b} & =\text { Lebar Benda Uji } \\
\mathrm{h} & =\text { Tebal Benda Uji }
\end{array}
$$

Tabel 4.1. Data Pandangan Luar Genteng

\begin{tabular}{cccccc}
\hline \multirow{2}{*}{ No } & \multirow{2}{*}{ Model Campuran } & \multicolumn{4}{c}{ Klasifikasi Genteng } \\
\cline { 3 - 6 } & & Permukaan Genteng & Warna & Suara & cacat \\
\hline 1 & Camp. I (10TL: 0 ASP) & Seragam, Utuh, halus & Merata, merah & Nyaring & Tidak \\
2 & Camp. II (10TL : 1 ASP) & Seragam, Utuh, halus & Merata, merah & Nyaring & Tidak \\
3 & Camp. III (10TL: 2 ASP) & Seragam, Utuh, halus & Merata, merah & Nyaring & Tidak \\
4 & Camp. IV (10TL: 3 ASP) & Seragam, Utuh, halus & Merata, merah & Nyaring & Tidak \\
5 & Camp. V (10TL: 4 ASP) & Seragam, Utuh, halus & Merah, merata & Nyaring & Tidak \\
6 & Camp. VI (10TL: 5 ASP) & Seragam, Utuh, halus & Merah, merata & Nyaring & Tidak \\
\hline
\end{tabular}

Sumber : Data Hasil Penelitian

NB : TL : Tanah Liat

Asp : Abu Sekam Padi

\section{HASIL PENELITIAN DAN PEMBAHASAN} Genteng sebagai benda uji penelitian adalah genteng tanah liat berbahan baku tanah liat dicampur dengan abu sekam padi, Pembuatan benda uji di Kec. Karang Penang Kabupaten Sampang. Metode yang dilakukan sesuai dengan metode yang dilakukan oleh tim produksi di Karang Penang Sampang dan teknik pencampuran bahan baku dilakukan dengan menggunakan mesin penggilas dan manual. Sedangkan untuk suhu pembakaran dilakukan dengan memperhatikan lama pembakaran sekitar 2 hari 3 malam.

\section{Bentuk dan Pandangan Luar}

Bentuk dan pandangan luar genteng yang dimaksud adalah tampilan fisik genteng yang bias diamati dan dinilai secara langsung dengan menggunakan indra dan menggunaka alat bantu sederhana sesuai dengan tata cara yang terdapat pada SNI 03-2095-1998. Hasil pengamatan dan 
pandangan luar genteng dapat dilihat pada table diatas.

Pengamatan visual terhadap semua genteng menunjukkan bahwa sebagian besar genteng berbentuk secara utuh (tidak retak, tidak terjadi kecacatan), namun terjadi perubahan yang berangsur pada setiap aspek penilaian akibat variasi penambahan Abu Sekam Padi pada setiap komposisi campuran bahan baku diantarannya:

1. Semua komposisi campuran bahan baku genteng yaitu 10 Tanah Liat (TL): 0 Abu Sekam Padi (ASP), $10 \mathrm{TL}: 1$ ASP, 10 TL : 2 ASP, 10 TL : 3 ASP, 10 TL : 4 ASP, 10 TL : 5 ASP ditinjau dari warna dan permukaan genteng semua rata dan halus dalam satu partai. Bahan baku campuran atau kandungan Abu Sekam Padi dalam semua komposisi semua genteng memiliki bentuk yang tidak cacat sesuai dengan SNI 03-20951998 yang mengacu pada SNI 03-20951991

2. Bahan baku campuran atau kandungan Abu Sekam Padi dalam semua komposisi semua genteng memiliki bentuk yang tidak cacat sesuai dengan SNI 03-2095-1998 yang mengacu pada SNI 03-2095-1991

3. Kenyaringan genteng pada keseluruhan bahan baku komposisi campuran rata-rata memiliki suara nyaring

\section{Ketetapan Ukuran Genteng}

Ketetapan ukuran genteng berdasarkan SNI 03-2095-1998. Menjelaskan bahwa bila di uji berdasarkan SNI 03-2095-1998 hal : 6 dengan cara 7.2 genteng untuk semua tingkat mutu harus memenuhi ukuran seperti pada Tabel 2. Hasil pengukuran terhadap benda uji genteng jenis genteng sedang sebagai objek penelitian ditunjukkan dalam tabel berikut. Pengamatan hasil pengujian genteng menunjukkan bahwa ukuran genteng adalah sama rata - rata ketetapan ukuran genteng sesuai dengan syarat dan ketentuan berdasarkan SNI 03-2095-1998 yang mengacu pada SNI 03-2095-1991

\section{Ketahanan Terhadap Rembesan Air}

Genteng sebagai penutup atap yang berfungsi melindungi penghuni bangunan dari panas dan air hujan, oleh sebab itu genteng hams memiliki ketahanan terhadap rembesan air. Genteng yang baik memiliki kekuatan menahan rembesan air minimal dua jam (120 menit). Artinya, genteng harus mampu menahan air tanpa terjadi rembesan atau penetesan minimal selama dua jam. Berikut tabel dan grafik hasil pengujian ketahanan genteng tanah liat Karang Penang Sampang.

Tabel 4.3 menunjukkan bahwa genteng dengan bahan baku tanah liat yang dicampur Abu Sekam Padi mampu menahan rembesan minimal selama 2 jam atau dengan kata lain air tidak mampu menetes/merembes dalam waktu dua jam.Dengan demikian bahwa genteng tanah liat tersebut telah memenuhi syarat SNI 032095-1998 yang mengacu pada SNI 032095-1991 dengan rembesan minimum harus lebih dari dua jam (120 menit).

\section{Peresapan Genteng}

Peresapan air pada genteng tanah liat yang dimaksud adalah kemapuan genteng dalam menyerap air sehingga kandungan air dalam genteng tercapai maksimum atau dengan kata lain genteng benar-benar jenuh air

Tabel 4.2. Data Ketepatan Ukuran Genteng

\begin{tabular}{|c|c|c|c|c|c|c|c|}
\hline \multirow[t]{2}{*}{ Ukuran } & \multicolumn{7}{|c|}{ Nilai Ukuran $(\mathbf{m m})$} \\
\hline & $\begin{array}{c}\text { SNI 03-2095- } \\
1998\end{array}$ & $\begin{array}{c}\text { Camp. VI } \\
\text { (10TL:4ASP) }\end{array}$ & $\begin{array}{c}\text { Camp. V } \\
\text { (10TL:3ASP) }\end{array}$ & $\begin{array}{c}\text { Camp. IV } \\
\text { (10TL:3ASP) }\end{array}$ & $\begin{array}{c}\text { Camp. III } \\
\text { (10TL:2ASP) }\end{array}$ & $\begin{array}{c}\text { Camp. II } \\
\text { (10TL:1ASP) }\end{array}$ & $\begin{array}{c}\text { Camp.I } \\
\text { (10TL:0ASP) }\end{array}$ \\
\hline $\begin{array}{l}\text { Panjang Berguna } \\
\text { jarak renggang } \\
\text { minimal }\end{array}$ & 250 & 250 & 250 & 250 & 250 & 250 & 250 \\
\hline $\begin{array}{l}\text { Lebar bergunan } \\
\text { minimal }\end{array}$ & 200 & 200 & 200 & 200 & 200 & 200 & 200 \\
\hline $\begin{array}{l}\text { Jarak Penutup } \\
\text { memnajng, } \\
\text { minimal }\end{array}$ & 60 & 60 & 60 & 60 & 60 & 60 & 60 \\
\hline Tinggi kaitan & 40 & 40 & 40 & 40 & 40 & 40 & 40 \\
\hline Panjang kaitan & 10 & 10 & 10 & 10 & 10 & 10 & 10 \\
\hline Lebar kaitan & 30 & 30 & 30 & 30 & 30 & 30 & 30 \\
\hline $\begin{array}{l}\text { Panjang Berguna } \\
\text { jarak renggang } \\
\text { minimal }\end{array}$ & 10 & 10 & 10 & 10 & 10 & 10 & 10 \\
\hline
\end{tabular}

Sumber : Data Peneitian 
Tabel 4.3. Data Peresapan Genteng Campuran I

\begin{tabular}{clccc}
\hline No & Model Campuran & $\begin{array}{c}\text { Meneteskan } \\
\text { air } \mathbf{( 1 2 0} \\
\text { menit) }\end{array}$ & $\begin{array}{c}\text { Tidak } \\
\text { menetesakan } \\
\text { air (120 menit) }\end{array}$ & $\begin{array}{c}\text { SNI 03-2095- } \\
\mathbf{1 9 9 1}\end{array}$ \\
\hline 1 & Campuran I (10TL:0ASP) & - & $\sqrt{ }$ & 120 \\
2 & Campuran II (10TL:1 ASP) & - & $\sqrt{ }$ & 120 \\
3 & Campuran III (10 TL: 2 ASP) & - & $\sqrt{ }$ & 120 \\
4 & Campuran IV (10 TL: 3 ASP) & - & $\sqrt{ }$ & 120 \\
5 & Campuran V (10 TL: 4 ASP) & - & $\sqrt{ }$ & 120 \\
6 & Campuran VI (10 TL: 5 ASP) & - & $\sqrt{ }$ & 120 \\
\hline
\end{tabular}

Sumber : Data Peneitian

Tabel 4.4. Data Peresapan Genteng Campuran I

\begin{tabular}{lllllll}
\hline \multirow{1}{*}{ Perlakuan } & \multicolumn{6}{c}{ Genteng Tanah Liat (10 TL : 0 ASP) } \\
\cline { 2 - 7 } & $\mathbf{1}$ & $\mathbf{2}$ & $\mathbf{3}$ & $\mathbf{4}$ & $\mathbf{5}$ & $\mathbf{6}$ \\
\hline Berat SSD, gram ( A ) & 546 & 450 & 448 & 457 & 432 & 323 \\
Berat Kering, gram (B) & 621 & 584 & 491 & 391 & 332 & 195 \\
Berat Genteng. gram (C) & 725 & 687 & 592 & 394 & 364 & 195 \\
Penyerapan Air, (\%) & 12,08 & 22,95 & 8,76 & 16,88 & 30,12 & 65,64 \\
Rata - rata & \multicolumn{5}{c}{6,89} \\
\hline
\end{tabular}

Sumber : Data Peneitian

Dari Tabel 4.4. diketahui bahwa penyerapan air pada genteng tanah liat dengan komposisi 10 Tanah Liat : 0 Abu Sekam Padi memiliki daya serap air dengan nilai rata-rata $6.89 \%$.

Tabel 4.5. Data Peresapan Genteng Campuran II

\begin{tabular}{lcccccc}
\hline \multirow{1}{*}{ Perlakuan } & \multicolumn{6}{c}{ Genteng Tanah Liat (10 TL : 0 ASP) } \\
\cline { 2 - 7 } & $\mathbf{1}$ & $\mathbf{2}$ & $\mathbf{3}$ & $\mathbf{4}$ & $\mathbf{5}$ & $\mathbf{6}$ \\
\hline Berat SSD, gram ( A ) & 456 & 450 & 559 & 335 & 523 & 547 \\
Berat Kering, gram (B) & 522 & 328 & 521 & 250 & 559 & 529 \\
Berat Genteng. gram (C) & 523 & 329 & 522 & 475 & 563 & 562 \\
Penyerapan Air, (\%) & 12,64 & 37,20 & 7,29 & 34,00 & 6,44 & 3,40 \\
Rata - rata & \multicolumn{6}{c}{6,28} \\
\hline
\end{tabular}

Sumber: Data Penelitian

Dari Tabel 4.5. diketahui bahwa penyerapan air pada genteng tanah liat dengan komposisi 10 Tanah Liat : 1 Abu Sekam Padi memiliki daya serap air dengan nilai rata-rata $6.28 \%$

Tabel 4.6. Data Peresapan Genteng Campuran II

\begin{tabular}{lcccccc}
\hline \multirow{1}{*}{ Perlakuan } & \multicolumn{6}{c}{ Genteng Tanah Liat (10 TL : 0 ASP) } \\
\cline { 2 - 7 } & $\mathbf{1}$ & $\mathbf{2}$ & $\mathbf{3}$ & $\mathbf{4}$ & $\mathbf{5}$ & $\mathbf{6}$ \\
\hline Berat SSD, gram ( A ) & 568 & 642 & 478 & 645 & 515 & 601 \\
Berat Kering, gram (B) & 629 & 450 & 473 & 574 & 490 & 560 \\
Berat Genteng. gram (C) & 630 & 412 & 475 & 574 & 492 & 562 \\
Penyerapan Air, (\%) & 9,70 & 42,67 & 1,06 & 12,37 & 5,10 & 7,32 \\
Rata - rata & \multicolumn{6}{c}{5,88} \\
\hline
\end{tabular}

Sumber: Data Penelitian

Dari Tabel 4.6. diketahui bahwa penyerapan air pada genteng tanah liat dengan komposisi 10 Tanah Liat : 2 Abu Sekam Padi memiliki daya serap air dengan nilai rata-rata 5,88\%. 
Tabel 4.7. Data Peresapan Genteng campuran IV

\begin{tabular}{lcccccc}
\hline \multirow{2}{*}{ Perlakuan } & \multicolumn{6}{c}{ Genteng Tanah Liat (10 TL : 0 ASP) } \\
\cline { 2 - 7 } & $\mathbf{1}$ & $\mathbf{2}$ & $\mathbf{3}$ & $\mathbf{4}$ & $\mathbf{5}$ & $\mathbf{6}$ \\
\hline Berat SSD, gram ( A ) & 445 & 589 & 536 & 514 & 310 & 389 \\
Berat Kering, gram (B) & 425 & 581 & 485 & 529 & 239 & 301 \\
Berat Genteng. gram (C) & 426 & 584 & 487 & 531 & 239 & 302 \\
Penyerapan Air, (\%) & 4,71 & 1,38 & 10,52 & $-2,84$ & 29,71 & 29,24 \\
Rata - rata & \multicolumn{5}{c}{7,27} \\
\hline
\end{tabular}

Sumber: Data Penelitian

Dari Tabel 4.7 diketahui bahwa penyerapan air pada genteng tanah liat dengan komposisi 10 Tanah Liat : 3 Abu Sekam Padi memiliki daya serap air dengan nilai rata-rata 7,27 \%

Tabel 4.8. Data Peresapan Genteng campuran V

\begin{tabular}{lcccccc}
\hline \multirow{2}{*}{ Perlakuan } & \multicolumn{6}{c}{ Genteng Tanah Liat (10 TL : 0 ASP) } \\
\cline { 2 - 7 } & $\mathbf{1}$ & $\mathbf{2}$ & $\mathbf{3}$ & $\mathbf{4}$ & $\mathbf{5}$ & $\mathbf{6}$ \\
\hline Berat SSD, gram ( A ) & 821 & 625 & 650 & 720 & 721 & 625 \\
Berat Kering, gram (B) & 745 & 589 & 650 & 606 & 737 & 420 \\
Berat Genteng. gram (C) & 847 & 590 & 651 & 607 & 739 & 421 \\
Penyerapan Air, (\%) & 10,20 & 6,11 & 0,00 & 18,81 & $-2,17$ & 48,81 \\
Rata - rata & \multicolumn{7}{c}{8,18} \\
\hline
\end{tabular}

Sumber: Data Penelitian

Dari Tabel 4.8 diketahui bahwa penyerapan air pada genteng tanah liat dengan komposisi 10 Tanah Liat : 4 Abu Sekam Padi memiliki daya serap air dengan nilai rata-rata 8,18\%

Tabel 4.9. Data Peresapan Genteng campuran VI

\begin{tabular}{lcccccc}
\hline \multirow{1}{*}{ Perlakuan } & \multicolumn{6}{c}{ Genteng Tanah Liat (10 TL : 0 ASP) } \\
\cline { 2 - 7 } & $\mathbf{1}$ & $\mathbf{2}$ & $\mathbf{3}$ & $\mathbf{4}$ & $\mathbf{5}$ & $\mathbf{6}$ \\
\hline Berat SSD, gram ( A ) & 528 & 815 & 668 & 779 & 842 & 562 \\
Berat Kering, gram (B) & 438 & 695 & 643 & 690 & 760 & 453 \\
Berat Genteng. gra m (C) & 445 & 697 & 644 & 731 & 762 & 454 \\
Penyerapan Air, (\%) & 20,55 & 17,27 & 3,89 & 12,90 & 10,79 & 24,06 \\
Rata - rata & \multicolumn{6}{c}{8,95} \\
\hline
\end{tabular}

Sumber : Data Penelitian

Tabel 4.10. Data Peresapan Rata-rata Genteng

\begin{tabular}{cc}
\hline Komposisi Campuran & Penyerapan Rata-rata (\%) \\
\hline 10 TL : 0 ASP & 6,89 \\
10 TL: 1 ASP & 8,28 \\
10 TL : 2 ASP & 5,88 \\
10 TL: 3 ASP & 7,21 \\
10 TL: $:$ ASP & 8,18 \\
10 TL : 5 ASP & 8,95 \\
\hline
\end{tabular}

Sumber : Data Penelitian

Berdasrkan table 4.10, Hasil rata-rata uji penyerapan yang dihasilkan oleh benda uji dapat digambar dengan grafik sebagai berikut: 


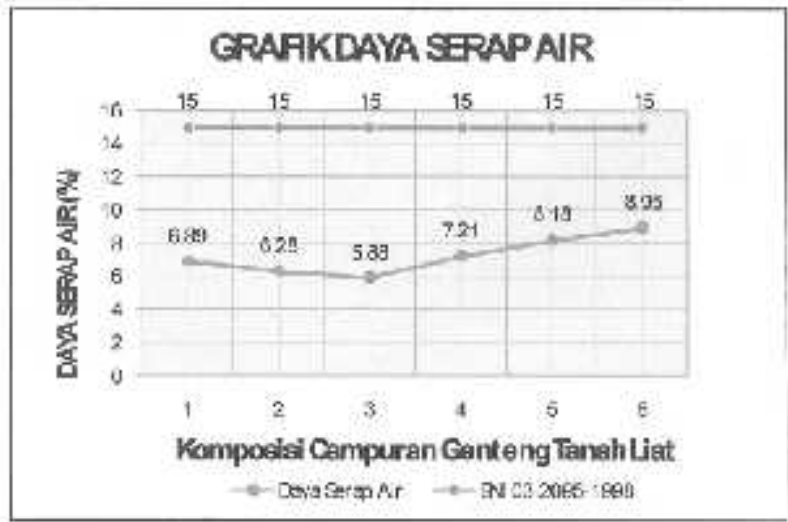

Grafik 4.1. Data Penyerapan Genteng

Tabel 4.11. Data Uji Kuat Lentur Genteng Campuran I

\begin{tabular}{|c|c|c|c|c|c|c|}
\hline \multirow[t]{2}{*}{ Perlakuan } & \multicolumn{6}{|c|}{ Genteng Tanah Liat (10 TL : 0 ASP) } \\
\hline & 1 & 2 & 3 & 4 & 5 & 6 \\
\hline Jarak Tumpu, (cm) & 25 & 25 & 25 & 25 & 25 & 25 \\
\hline Lebar Genteng, (cm) & 20 & 20 & 20 & 20 & 20 & 20 \\
\hline Tebal Genteng, $(\mathrm{cm})$ & 11 & 11 & 11 & 11 & 11 & 11 \\
\hline Panjang Genteng, (cm) & 30 & 30 & 30 & 30 & 30 & 30 \\
\hline Beban Lentur, $(\mathrm{Kg})$ & 165,8 & 165,8 & 154,3 & 154,3 & 160,3 & 160,3 \\
\hline Rata-rata Beban Lentur, (Kg) & \multicolumn{6}{|c|}{160,13} \\
\hline Tegangan Lentur, $(\mathrm{Kg} / \mathrm{cm})$ & 308,31 & 308,31 & 286,92 & 286,92 & 298,08 & 298,08 \\
\hline Rata-rata Tegangan Lentur, $(\mathrm{Kg} / \mathrm{cm})$ & \multicolumn{6}{|c|}{297,77} \\
\hline
\end{tabular}

Sumber : Data Penelitian

Dari Tabel dan grafik 4.2. Diketahui bahwa campuran dengan komposisi 10 Tanah Liat : 0 Abu Sekam Padi mempunyai penyerapan air sebesar 6,89\%, pada komposisi 10 TL : 1 ASP mempunyai penyerapan air sebesar $6,28 \%$, pada komposisi 10 TL : 2 ASP mempunyai penyerapan air sebesar $5,88 \%$, pada komposisi $10 \mathrm{TL}$ : 3 ASP mempunyai penyerapan air sebesar $7,21 \%$, pada komposisi 10 TL : 4 ASP mempunyai penyerapan air sebesar $8,18 \%$, pada komposisi $10 \mathrm{TL}$ : 5 ASP mempunyai penyerapan air sebesar 8,95\%

Dari data yang ada, penyerapan air tertinggi ada pada genteng tanah liat dengan penambahan Abu Sekam Padi pada komposisi 10 Tanah Liat: 5 Abu Sekam Padi yaitu sebesar $8,95 \%$ dan hasil penyerapan terendah terdapat pada genteng tanah liat dengan penambahan Abu Sekam Padi pada komposisi 10 Tanah Liat: 3 Abu Sekam Padi sebesar $5,88 \%$.

\section{Kekuatan Genteng Terhadap Beban Lentur}

Kekuatan lentur maksimum genteng adalah kemampuan maksimum genteng dalam menahan beban. Genteng tanah liat harus mempunyai beban lentur rata-rata minimum menurut SNI 03-2095-1998 yang mengacu pada SNI 03-20995-1991 untuk 6 buah genteng yang diuji sebesar $110 \mathrm{~kg}$ untuk genteng tingkat mutu II, dan beban lentur minimum masing-masing genteng yang diuji $90 \mathrm{~kg}$

Dari tabel 4.11 menunjukkan bahwa rata-rata dari beban lentur genteng tanah liat komposisi $10 \mathrm{TL}$ : 0 ASP sebesar $160,13 \mathrm{~kg}$, sedangkan untuk rata-rata kuat tegangan lentur sebesar 297,77 kg/ $\mathrm{cm}^{2}$. Genteng tanah liat campuran I untuk kuat lentur masuk mutu II (SNI 03-2009-1998) 
Tabel 4.12. Data Uji Kuat Lentur Genteng Campuran II

\begin{tabular}{|c|c|c|c|c|c|c|}
\hline \multirow[t]{2}{*}{ Perlakuan } & \multicolumn{6}{|c|}{ Genteng Tanah Liat (10 TL : 0 ASP) } \\
\hline & 1 & 2 & 3 & 4 & 5 & 6 \\
\hline Jarak Tumpu, (cm) & 25 & 25 & 25 & 25 & 25 & 25 \\
\hline Lebar Genteng, $(\mathrm{cm})$ & 20 & 20 & 20 & 20 & 20 & 20 \\
\hline Tebal Genteng, (cm) & 11 & 11 & 11 & 11 & 11 & 11 \\
\hline Panjang Genteng, (cm) & 30 & 30 & 30 & 30 & 30 & 30 \\
\hline Beban Lentur, $(\mathrm{Kg})$ & 166,7 & 155,7 & 158,7 & 155,7 & 175,71 & 175,7 \\
\hline Rata-rata Beban Lentur, $(\mathrm{Kg})$ & \multicolumn{6}{|c|}{164,70} \\
\hline Tegangan Lentur, $(\mathrm{Kg} / \mathrm{cm})$ & 309,98 & 289,52 & 295,10 & 289,52 & 326,71 & 326,71 \\
\hline Rata-rata Tegangan Lentur, $(\mathrm{Kg} / \mathrm{cm})$ & \multicolumn{6}{|c|}{306,26} \\
\hline
\end{tabular}

Sumber : Data Penelitian

Dari tabel 4.12 menunjukkan bahwa rata-rata dari beban lentur genteng tanah liat komposisi $10 \mathrm{TL}$ : 1 ASP sebesar $164,70 \mathrm{~kg}$, sedangkan untuk rata-rata kuat tegangan lentur sebesar $306,26 \mathrm{~kg} / \mathrm{cm}^{2}$. Genteng tanah liat campuran II untuk kuat lentur masuk mutu II (SNI 032009-1998)

Tabel 4.13. Data Uji Kuat Lentur Genteng Campuran III

\begin{tabular}{|c|c|c|c|c|c|c|}
\hline \multirow[t]{2}{*}{ Perlakuan } & \multicolumn{6}{|c|}{ Genteng Tanah Liat (10 TL : 0 ASP) } \\
\hline & 1 & 2 & 3 & 4 & 5 & 6 \\
\hline Jarak Tumpu, (cm) & 25 & 25 & 25 & 25 & 25 & 25 \\
\hline Lebar Genteng, (cm) & 20 & 20 & 20 & 20 & 20 & 20 \\
\hline Tebal Genteng, (cm) & 11 & 11 & 11 & 11 & 11 & 11 \\
\hline Panjang Genteng, (cm) & 30 & 30 & 30 & 30 & 30 & 30 \\
\hline Beban Lentur, $(\mathrm{Kg})$ & 188,5 & 167,7 & 167,7 & 168,6 & 168,6 & 157,6 \\
\hline Rata-rata Beban Lentur, $(\mathrm{Kg})$ & \multicolumn{6}{|c|}{169,95} \\
\hline Tegangan Lentur, $(\mathrm{Kg} / \mathrm{cm})$ & 350,52 & 311,84 & 311,84 & 313,51 & 313,51 & 294,92 \\
\hline Rata-rata Tegangan Lentur, $(\mathrm{Kg} / \mathrm{cm})$ & \multicolumn{6}{|c|}{316,02} \\
\hline
\end{tabular}

Sumber : Data Penelitian

Dari tabel 4.13 menunjukkan bahwa rata-rata dari beban lentur genteng tanah liat komposisi $10 \mathrm{TL}$ : 2 ASP sebesar 169,95 $\mathrm{kg}$, sedangkan untuk rata-rata kuat tegangan lentur sebesar $316,02 \mathrm{~kg} / \mathrm{cm}^{2}$. Genteng tanah liat campuran II untuk kuat lentur masuk mutu II (SNI 032009-1998)

Tabel 4.14. Data Uji Kuat Lentur Genteng Campuran IV

\begin{tabular}{|c|c|c|c|c|c|c|}
\hline \multirow[t]{2}{*}{ Perlakuan } & \multicolumn{6}{|c|}{ Genteng Tanah Liat (10 TL : 0 ASP) } \\
\hline & 1 & 2 & 3 & 4 & 5 & 6 \\
\hline Jarak Tumpu, (cm) & 25 & 25 & 25 & 25 & 25 & 25 \\
\hline Lebar Genteng, (cm) & 20 & 20 & 20 & 20 & 20 & 20 \\
\hline Tebal Genteng, (cm) & 11 & 11 & 11 & 11 & 11 & 11 \\
\hline Panjang Genteng, (cm) & 30 & 30 & 30 & 30 & 30 & 30 \\
\hline Beban Lentur, $(\mathrm{Kg})$ & 168,7 & 168,7 & 158,7 & 158,7 & 128,8 & 128,8 \\
\hline Rata-rata Beban Lentur, (Kg) & \multicolumn{6}{|c|}{152,05} \\
\hline $\begin{array}{l}\text { Tegangan Lentur, }(\mathrm{Kg} / \mathrm{cm}) \\
\text { Rata-rata Tegangan Lentur, }(\mathrm{Kg} / \mathrm{cm})\end{array}$ & 313,70 & 313,51 & $\begin{array}{r}295,10 \\
28\end{array}$ & $\begin{array}{l}295,10 \\
74\end{array}$ & 239,50 & 239,50 \\
\hline
\end{tabular}

Sumber : Data Penelitian

Dari tabel 4.14 menunjukkan bahwa rata-rata dari beban lentur genteng tanah liat komposisi $10 \mathrm{TL}$ : 3 ASP sebesar $152,05 \mathrm{~kg}$, sedangkan untuk rata-rata kuat tegangan lentur sebesar $282,74 \mathrm{~kg} / \mathrm{cm}^{2}$. Genteng tanah liat campuran II untuk kuat lentur masuk mutu II (SNI 032009-1998) 
Tabel 4.15. Data Uji Kuat Lentur Genteng Campuran V

\begin{tabular}{|c|c|c|c|c|c|c|}
\hline \multirow[t]{2}{*}{ Perlakuan } & \multicolumn{6}{|c|}{ Genteng Tanah Liat (10 TL : 0 ASP) } \\
\hline & 1 & 2 & 3 & 4 & 5 & 6 \\
\hline Jarak Tumpu, (cm) & 25 & 25 & 25 & 25 & 25 & 25 \\
\hline Lebar Genteng, (cm) & 20 & 20 & 20 & 20 & 20 & 20 \\
\hline Tebal Genteng, (cm) & 11 & 11 & 11 & 11 & 11 & 11 \\
\hline Panjang Genteng, (cm) & 30 & 30 & 30 & 30 & 30 & 30 \\
\hline Beban Lentur, $(\mathrm{Kg})$ & 135,8 & 152,2 & 152,2 & 136,8 & 136,8 & 135,8 \\
\hline Rata-rata Beban Lentur, (Kg) & & & & & & \\
\hline $\begin{array}{l}\text { Tegangan Lentur, }(\mathrm{Kg} / \mathrm{cm}) \\
\text { Rata-rata Tegangan Lentur, }(\mathrm{Kg} / \mathrm{cm})\end{array}$ & 252,52 & 283,02 & $\begin{array}{r}283,02 \\
26\end{array}$ & 254,38 & 254,38 & 252,52 \\
\hline
\end{tabular}

Dari tabel 4.15 menunjukkan bahwa rata-rata dari beban lentur genteng tanah liat komposisi 10 TL : 4 ASP sebesar $141,60 \mathrm{~kg}$, sedangkan untuk rata-rata kuat tegangan lentur sebesar $263,31 \mathrm{~kg} / \mathrm{cm}^{2}$. Genteng tanah liat campuran II untuk kuat lentur masuk mutu II (SNI 032009-1998)

Tabel 4.16. Data Uji Kuat Lentur Genteng Campuran VI

\begin{tabular}{|c|c|c|c|c|c|c|}
\hline \multirow[t]{2}{*}{ Perlakuan } & \multicolumn{6}{|c|}{ Genteng Tanah Liat (10 TL : 0 ASP) } \\
\hline & 1 & 2 & 3 & 4 & 5 & 6 \\
\hline Jarak Tumpu, (cm) & 25 & 25 & 25 & 25 & 25 & 25 \\
\hline Lebar Genteng, (cm) & 20 & 20 & 20 & 20 & 20 & 20 \\
\hline Tebal Genteng, $(\mathrm{cm})$ & 11 & 11 & 11 & 11 & 11 & 11 \\
\hline Panjang Genteng, (cm) & 30 & 30 & 30 & 30 & 30 & 30 \\
\hline Beban Lentur, $(\mathrm{Kg})$ & 142,36 & 142,36 & 128,4 & 128,4 & 130,26 & 130,26 \\
\hline Rata-rata Beban Lentur, (Kg) & \multicolumn{6}{|c|}{133,67} \\
\hline $\begin{array}{l}\text { Tegangan Lentur, }(\mathrm{Kg} / \mathrm{cm}) \\
\text { Rata-rata Tegangan Lentur, }(\mathrm{Kg} / \mathrm{cm})\end{array}$ & 264,72 & 264,72 & $\begin{array}{r}238,76 \\
24\end{array}$ & $\begin{array}{l}238,76 \\
57\end{array}$ & 242,22 & 242,22 \\
\hline
\end{tabular}

Sumber : Data Penelitian

Dari tabel 4.16 menunjukkan bahwa rata-rata dari beban lentur genteng tanah liat komposisi $10 \mathrm{TL}$ : 5 ASP sebesar 133,67 kg, sedangkan untuk rata-rata kuat tegangan lentur sebesar $248,57 \mathrm{~kg} / \mathrm{cm}^{2}$. Genteng tanah liat campuran II untuk kuat lentur masuk mutu II (SNI 032009-1998).

Tabel 4.17. Hasil Perhtiungan Rata-rata Uji Kuat Lentur

\begin{tabular}{ccc}
\hline $\begin{array}{c}\text { Komposisi } \\
\text { Campuran }\end{array}$ & $\begin{array}{c}\text { Beban Lentur } \\
\text { Rata-rata }(\mathbf{K g})\end{array}$ & $\begin{array}{c}\text { Tegangan Lentur } \\
\text { Rata-rata }\left(\mathbf{K g} / \mathbf{~ c m}^{2}\right)\end{array}$ \\
\hline 10TL:0 ASP & 160,13 & 297,77 \\
10 TL: 1 ASP & 164,70 & 306,26 \\
10 TL : : ASP & 169,95 & 316,02 \\
10 TL : $\mathbf{~ A S P ~}$ & 152,05 & 282,74 \\
10 TL : 4 ASP & 141,60 & 263,31 \\
10 TL : 5 ASP & 133,67 & 248,57 \\
Sumber : Data Penelitian
\end{tabular}

Dari Bedasarkan table 4.17. hasil rata-arat kuat lentur yang dihasilakn oleh benda uji dapat digambar dengan grafik sebgai berikut.

Dari hasil perhitungan rata-rata uji lentur diatas dapat ditabelkan sebagai berikut 


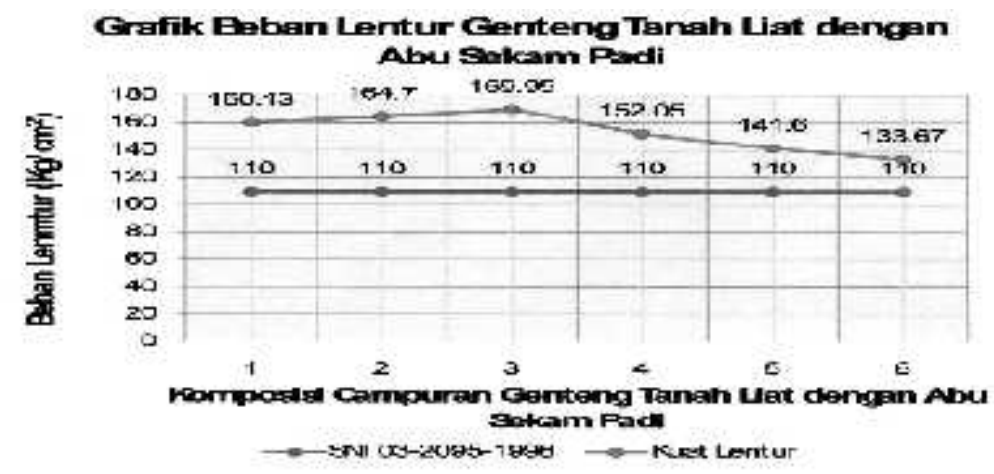

Grafik 4.2. Data Beban Perhitungan Rata-rata Uji Kuat Lentur

Sedangkan data dari tegangan lentur rata-rata yang dihasilkan oleh benda uji dapat digambar sengan grafik sebagai berikut.

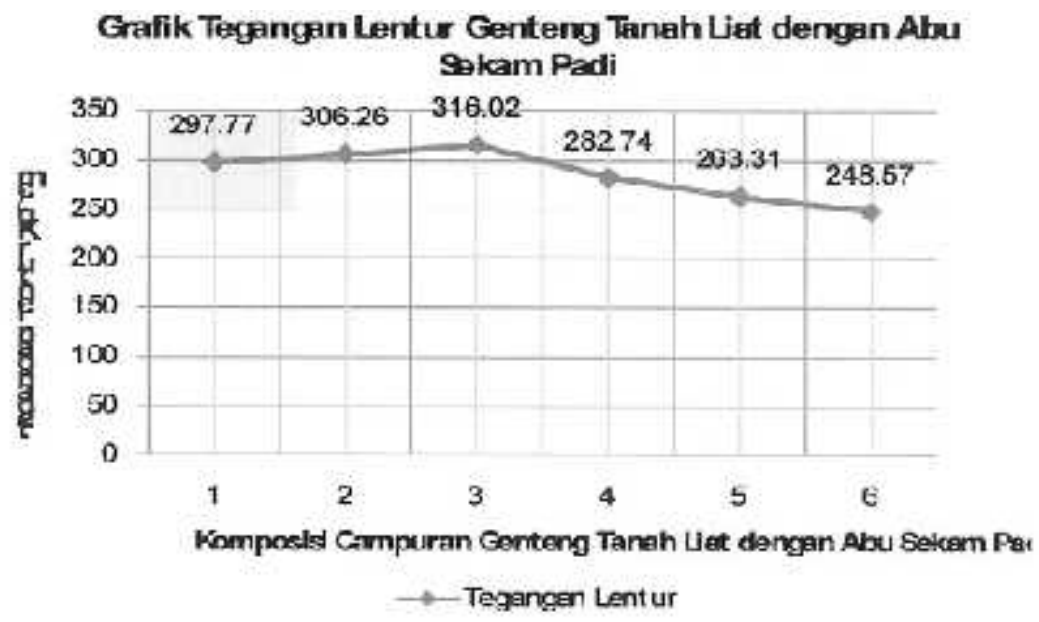

Grafik 4.3. Data Tegangan Lentur Genteng Tanah Liat

Tabel 4.18. Data Rekapitulasi Penelitian Genteng Tanah Liat

\begin{tabular}{lcccccc}
\hline \multirow{3}{*}{ Aspek Penelitian } & \multicolumn{7}{c}{ Nilai Mutu } \\
\cline { 2 - 7 } & Camp. I & Camp. II & Camp. III & Camp. IV & Camp. V & Camp. VI \\
& 10TL:0ASP & 10TL:1ASP & 10TL:2ASP & 10TL:3ASP & 10TL.-4ASP & 10TL:5ASP \\
\hline Bentuk dan & memenuhi & memenuhi & memenuhi & memenuhi & memenuhi & memenuhi \\
pandangan luar & syarat & syarat & syarat & syarat & syarat & syarat \\
Keteapan Ukuran & memenuhi & memenuhi & memenuhi & memenuhi & memenuhi & memenuhi \\
& syarat & syarat & syarat & syarat & syarat & syarat \\
Kekuatan Genteng & II & II & II & 11 & II & II \\
Rembewan air & $>2$ Jam & $>2 \mathrm{Jam}$ & $>2 \mathrm{Jam}$ & $>2 \mathrm{Jam}$ & $>2 \mathrm{Jam}$ & $>2 \mathrm{Jam}$ \\
\hline
\end{tabular}

Sumber : Data Penelitian

Rekapitulasi Mutu GentengMenurut SNI 03-2095-1998 yang mengacu pada SNI 032095-1991

Penelitian yang dilakukan terhadap genteng tanah liat ukuran sedang, berbahan tanah liat dan tambahan Abu Sekam Padi dengan enam variasi komposisi yaitu 10 Tanah Liat (TL) : 0 Abu Sekam Padi (ASP),
$10 \mathrm{TL}: 1$ ASP, $10 \mathrm{TL}: 2 \mathrm{ASP}, 10 \mathrm{TL}: 3$ ASP, $10 \mathrm{TL}: 4 \mathrm{ASP}, 10 \mathrm{TL}: 5 \mathrm{ASP}$ menunjukan bahwa dari segi bentuk dan pandangan luar genteng tanah liat telah memenihu syarat sesuai dengan SNI 032095-1998 yang mengacu pada SNI 032095-1991. Sedangkan dilihat dari segi ketepatan ukuran seluruh genteng tanah liat 
dengan bahan baku campuran Abu Sekam Padi ketepatan ukuran genteng Karang Penang Sampang sesuai dengan SNI 032095-1998 yang mengacu pada SNI 032095-1991.

Adapun kemampuan rembesan dalam menahan rembesan air, menunjukkan bahwa kandungan Abu Sekam Padi dalam beberapa komposisi campuran mampu menahan rembesan selama waktu yang ditetapkan dalam SNI 03-2095-1998 yaitu minimum 120 menit atau 2 jam, sedangkan untuk kekuatan lentur pada campuran III menunjukkan nilai tertinggi kuat lentur sebesar $169.95 \mathrm{Kg}$ dan masuk dalam tingkat mutu genteng II. Berikut ini hasil penelitian ditinjau berdasrkan SNI 03-2095-1998 yang mengacu pada SNI 03-2095-1991.

Rekapitulasi hasil penelitian terhadap genteng tanah liat dari Karang Penang Sampang menunjukkan bahwa :

1. Genteng komposisi bahan baku tanah liat dengan komposisi campuran Abu Sekam Padi merupakan genteng dengan tingkat mutu II sesuai dengan SNI 03-2095-1998 yang mengacu pada SNI 03-2095-1991 dengan beban lentur maksimum sebesar $169.95 \mathrm{Kg}$, sedangkan menurut SNI 03-2095-1998 minimum sebesar $110 \mathrm{Kg}$ namun secara keseluruhan genteng telah memenuhi syarat untuk tingkat mutu genteng II.

2. Genteng dengan seluruh komposisi campuran bahan Abu Sekam Padi menurut SNI 03-2095-1998 yang mengacu pada SNI 03-2095-1991 untuk ketepatan bentuk dan pandangan luar genteng seluruhnya memenuhi syarat tersebut.

3. Genteng dengan seluruh komposisi campuran masing-masing mampu menahan rembesan air sesuai dengan SNI 03-2095-1998 yang mengacu pada SNI 03-2095-1991 yaitu minimum 120 menit atau dua jam.

\section{SIMPULAN}

Dari data dan hasil analisa yang didapat maka dapat disimpulkan bahwa Abu Sekam Padi dapat dijadikan sebagai campuran bahan baku pembuatan genteng tanah liat di Karang Penang Sampang. Untuk komposisi campuran yang terbaik adalah komposisi campuran Abu Sekam Padi tidak melebihi komposisi campuran 10 lanah Liat : 2 Abu Sekam Padi agar menghasilkan genteng terbaik dalam uji kuat lentur, daya serap serta rembesan berdasarkan Standart Nasional Indonesia (SNI

03-2095-1998).

\section{DAFTAR PUSTAKA}

Harianto, R. 2008. "Pengaruh Agregat Lumpur Lapindo di Desa Siring Kabupaten Sidoarjo Sebagai Bahan Tambahan Pada Pembuatan Genteng Tanah Liat Berglazir Yang Berstandart SNI 03-2134-1996". Surabaya: FT PTB Unesa

I Nyoman Ringsun. 2004,. "IImu Bahan Bangunan". Surabaya. Unesa University Press.

Passaribu, Ramus, Tampa Tahun "Analisa Kemampuan Beton Ringan-Abu Sekam Padi" Disertasi yang tidak dipublikasikan Jakarta. Universitas Tarumanegara

Sinambela P. 1993. "Penelitian Pemannfatan Abu Sekam Padi Sebagai Kebutuhan Rumah Tangga" Badan Penelitian Dan Pengembangan Industri. Manado

Standart Nasional Indonesia "SNI 03-2095-1991 Genteng Keramik". Badan Standardisasi Nasional - BSN.

Standart Nasional Indonesia "SNI 03-2095-1998" Genteng Keramik". Badan Standardisasi Nasional - BSN.

Suprapto. 2005. "Panduan Uji Bahan Bangunan". Direktorat Jendral Pendidikan Tinggi Universitas Negeri Surabaya

Universitas Negeri Surabaya. 2006 "Panduan Penulisan dan Penilaian Skripsi" Surabaya. Unesa University Press. 